\section{Preliminary stages of a cross-cultural Brazilian Portuguese adaptation of a measurement tool for assessing public understanding of human papillomavirus}

\author{
Etapas preliminares da adaptação transcultural para \\ o Português de um intrumento de aferição do \\ conhecimento sobre o papilomavírus humano
}

\section{Etapas preliminares de una adaptación cultural al portugués de una herramienta de medición para evaluar la comprensión pública de virus del papiloma humano}

André Luciano Manoel 1 Jefferson Traebert 1 Luísa Correa Rebello 1 Clávison Martinelli Zapelini 1 Daisson José Trevisol 1,2

Fabiana Schuelter-Trevisol 1,2

\begin{abstract}
The objective of this study was to conduct the initial stages of the crosscultural adaptation to Brazilian Portuguese of a scale to measure the level of knowledge about HPV. The stages included: translation from English into the Portuguese spoken in Brazil; synthesis of the translated version; back-translation; analysis by an expert committee; and reliability analysis based on internal consistency and reproducibility. Cronbach's a coefficient for the instrument was 0.985. Subset analysis produced only minor variations. The correlation coefficients between the individual items and the overall result showed strong positive correlations, except for three items. Reproducibility analysis showed kappa values with substantial or moderate agreement for the majority of the items. A preliminary Brazilian version was obtained with satisfactory results, but other stages are necessary in the process of validation of the Brazilian version.
\end{abstract}

Papillomaviridae; Papillomavirus Vaccines; Questionnaires

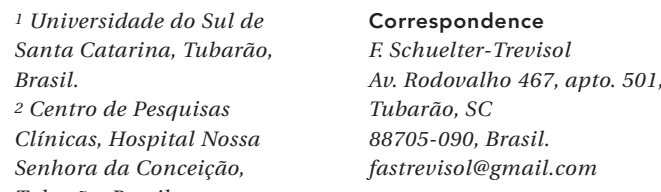




\section{Introduction}

The human papillomavirus (HPV) is one of the main viruses that cause cancer, especially cervical cancer 1.

The Brazilian Federal government launched an HPV immunization campaign in 2014 (Brazilian Ministry of Health. http://pni.datasus.gov. br/consulta_hpv_14_C01.php). The campaign has raised social and ethical discussions on the fact that vaccination against a sexually transmitted virus is being targeted to young girls. Lack of the population's knowledge on HPV may explain some parents' reluctance to have their daughters vaccinated.

Waller et al. 2 developed a scale to measure the level of knowledge on HPV, the only validated tool for this purpose. The "Measure of Knowledge about HPV" consists of 29 statements divided into three subscales, one on HPV, one on the vaccine, and the last on the HPV test. Interviewees are asked to check "true", "false", or "I don't know" for each of the statements.

Since public understanding of HPV vaccination can play a key role in the success of this preventive measure by the Brazilian public health system, the current study developed the preliminary stages of cross-cultural adaptation of a measure of knowledge and awareness about HPV, previously validated in English 2.

\section{Methods}

This was a cross-sectional study to begin the cultural adaptation of a self-administered questionnaire. Individuals invited to participate in the study were parents of children 9 to 13 years of age living in southern Santa Catarina State, Brazil, who were able to answer the online questionnaire. Parents of students enrolled in both public and private schools were recruited. Online invitations were sent to 90 parents, asking them to access the link to the questionnaire. A nonprobabilistic sampling plan was used.

All steps in this process followed the criteria suggested by Beaton et al. ${ }^{3}$. A sample size of at least 30 subjects was suggested for the preliminary stage of the cross-cultural adaptation.

Two Brazilians with good knowledge of English translated the questionnaire from the source language to the target language. One translator had a health background and knew the study objectives, and the other had a Master's degree in linguistics was blinded to the study objectives.

The authors compared the two versions and merged them into a third version, which was used as the questionnaire's primary Brazilian version.
Back-translation was performed independently by two individuals. Both were native English speakers and had extensive experience with Brazilian Portuguese. From the two back-translated versions, the authors formulated a third version in English, which was compared to the original version in the source language.

The expert committee consisted of the study's authors plus a researcher in sexually transmitted diseases, an expert in language and linguistics, a $\mathrm{PhD}$ student in health sciences who was knowledgeable on technologies required for cross-cultural adaptation, and two epidemiologists.

The expert committee's role was to review all steps in the process and evaluate the semantic, idiomatic, experiential, and conceptual equivalences. The process was completed with the preparation of the questionnaire's prefinal version.

In the first stage, 32 subjects completed the questionnaire, aimed at analyzing internal consistency. Reliability was assessed through internal consistency and reproducibility analysis.

After informed consent was obtained, a link to the questionnaire Brazilian version was provided, using Google Docs (https://www.google com/docs). This software generated a database in MS Excel 2013 (Microsoft Corp., USA), exported to SPSS v. 20 (IBM Corp., Armonk, USA), on which the statistical analyses were performed.

In a second stage, 39 subjects completed the questionnaire on two occasions with a 10-15-day interval. Reproducibility analysis was performed using the same software cited in the previous stage. Internal consistency was obtained through Cronbach's $\alpha$; intra-observer reliability was estimated with the kappa coefficient; and correlation between items and the instrument's overall result was observed by means of the Spearmen rank correlation coefficient. The research project was approved by the Ethics Research Committee of the University of Southern Santa Catarina, under protocol number 734735 .

\section{Results}

During the process of translation and crosscultural adaptation, some expressions had to be reworded to fit the Brazilian context. Most of the significant changes were made in the introduction to the questionnaire. One change was the phrase "cervical cancer", which was translated as câncer de colo de útero (cancer of the uterine cervix).

Some details were detected by the translators and back-translators and discussed by the expert committee. The English word "condom" can have 
different translations in Portuguese. A rather formal equivalent is preservativo, but condom can also be translated more informally as camisinha. We preferred the term camisinha masculina e feminina (male and female condoms) on grounds that it would be understood more easily by the Brazilian general population.

The Brazilian version of the measurement tool showed excellent internal consistency, with Cronbach's $\alpha$ of 0.985 . Subset analysis showed little variation: 0.999 for the first subset, 0.996 for the second, and 0.998 for the third. The correlation coefficients between each item and the overall result showed strong positive correlations, ranging from 0.904 to 0.949 . Exceptions were the results of the last three items in subset 3 (Table 1). Table 1 shows the kappa values used for measuring reproducibility through test and retest at 10-15-day intervals.

Table 1

Correlation coefficients between items and overall result, Cronbach's $\alpha$ for items that were disregarded, and kappa coefficients. Brazilian version of a measure of knowledge about human papillomavirus (HPV) and HPV vaccination.

\begin{tabular}{|c|c|c|c|}
\hline Items & $\begin{array}{l}\text { Correlation between } \\
\text { items and overall result * }\end{array}$ & $\begin{array}{l}\text { Cronbach's } \alpha \text { if the item } \\
\text { was disregarded * }\end{array}$ & $\begin{array}{l}\text { Kappa test } \\
\text { and re-test ** }\end{array}$ \\
\hline \multicolumn{4}{|l|}{ Subset 1} \\
\hline $\begin{array}{l}\text { 1a. HPV can cause cervical cancer // O HPV pode causar câncer } \\
\text { de colo de útero. }\end{array}$ & $0.949(0.920-0.971)$ & $0.984(0.975-0.991)$ & $0.654(0.026-1.000)$ \\
\hline $\begin{array}{l}\text { 1b. A person could have HPV for many years without knowing it } \\
\text { // Uma pessoa pode ter HPV por muitos anos sem saber. }\end{array}$ & $0.941(0.908-0.966)$ & $0.984(0.975-0.991)$ & $1.000(1.000-1.000)$ \\
\hline $\begin{array}{l}\text { 1c. Having many sexual partners increases the risk of getting } \\
\text { HPV // Ter muitos parceiros sexuais aumenta o risco de contrair } \\
\text { HPV. }\end{array}$ & $0.945(0.914-0.969)$ & $0.984(0.975-0.991)$ & $0.786(0.381-1.000)$ \\
\hline $1 \mathrm{~d} . \mathrm{HPV}$ is very rare // O HPV é muito raro. & $0.949(0.920-0.971)$ & $0.984(0.975-0.991)$ & $0.471(-0.153-1.000)$ \\
\hline $\begin{array}{l}\text { 1e. HPV can be passed on during sexual intercourse // O HPV } \\
\text { pode ser transmitido nas relações sexuais. }\end{array}$ & $0.942(0.909-0.967)$ & $0.984(0.975-0.991)$ & $0.357(-0.202-0.922)$ \\
\hline $\begin{array}{l}\text { 1f. HPV always has visible signs or symptoms // O HPV sempre } \\
\text { apresenta sinais ou sintomas. }\end{array}$ & $0.904(0.850-0.945)$ & $0.984(0.975-0.991)$ & $0.437(-0.023-0.898)$ \\
\hline $\begin{array}{l}\text { 1g. Using condoms reduces the risk of getting HPV // Usar } \\
\text { camisinha (preservativo masculino ou feminino) diminui o risco } \\
\text { de contrair HPV. }\end{array}$ & $0.949(0.920-0.971)$ & $0.984(0.975-0.991)$ & $0.478(-0.121-1.000)$ \\
\hline 1h. HPV can cause HIV/AIDS // O HPV pode causar HIV/AIDS. & $0.927(0.886-0.959)$ & $0.984(0.975-0.991)$ & $0.719(0.350-1.000)$ \\
\hline $\begin{array}{l}\text { 1i. HPV can be passed on by genital skin-to-skin contact // O } \\
\text { HPV pode ser transmitido pelo contato direto com a pele das } \\
\text { partes genitais. }\end{array}$ & $0.934(0.887-0.963)$ & $0.984(0.975-0.991)$ & $0.544(0.268-0.820)$ \\
\hline 1j. Men cannot get HPV // Homens não contraem HPV. & $0.934(0.887-0.963)$ & $0.984(0.975-0.991)$ & $0.620(0.228-1.000)$ \\
\hline $\begin{array}{l}\text { 1k. Having sex at an early age increases the risk of getting HPV } \\
\text { // Ter relações sexuais em idade precoce aumenta o risco de } \\
\text { contrair HPV. }\end{array}$ & $0.928(0.888-0.959)$ & $0.984(0.975-0.991)$ & $0.636(0.389-0.084)$ \\
\hline $\begin{array}{l}\text { 1I. There are many types of HPV // Existem muitos tipos de } \\
\text { HPV. }\end{array}$ & $0.925(0.883-0.957)$ & $0.984(0.975-0.991)$ & $0.800(0.533-1.000)$ \\
\hline $\begin{array}{l}1 \mathrm{~m} . \mathrm{HPV} \text { can cause genital warts // O HPV pode causar } \\
\text { verrugas genitais. }\end{array}$ & $0.943(0.911-0.968)$ & $0.984(0.975-0.991)$ & $0.842(0.541-1.000)$ \\
\hline $\begin{array}{l}\text { 1n. HPV can be cured with antibiotics // O HPV pode ser } \\
\text { curado com antibióticos. }\end{array}$ & $0.911(0.861-0.949)$ & $0.984(0.975-0.991)$ & $0.832(0.651-1.000)$ \\
\hline $\begin{array}{l}\text { 1p. Most sexually active people will get HPV at some point } \\
\text { in their lives // A maioria das pessoas sexualmente ativas vai } \\
\text { contrair HPV em algum momento de suas vidas. }\end{array}$ & $0.923(0.880-0.956)$ & $0.984(0.975-0.991)$ & $0.588(0.320-0.856)$ \\
\hline $\begin{array}{l}\text { 1q. HPV usually doesn't need any treatment // Geralmente o } \\
\text { HPV não precisa de tratamento. }\end{array}$ & $0.948(0.919-0.970)$ & $0.984(0.975-0.991)$ & $0.759(0.537-0.981)$ \\
\hline
\end{tabular}

(continues) 
Table 1 (continued)

\begin{tabular}{|c|c|c|c|}
\hline Items & $\begin{array}{l}\text { Correlation between } \\
\text { items and overall result * }\end{array}$ & $\begin{array}{l}\text { Cronbach's } \alpha \text { if the item } \\
\text { was disregarded * }\end{array}$ & $\begin{array}{l}\text { Kappa test } \\
\text { and re-test ** }\end{array}$ \\
\hline \multicolumn{4}{|l|}{ Subset 2} \\
\hline $\begin{array}{l}\text { 2a. Girls who have had an HPV vaccine do not need a Pap test } \\
\text { when they are older // As meninas que forem vacinadas contra } \\
\text { o HPV não precisam fazer o exame de Papanicolau quando } \\
\text { forem mais velhas. }\end{array}$ & $0.945(0.914-0.969)$ & $0.984(0.975-0.991)$ & $0.536(0.141-0.932)$ \\
\hline $\begin{array}{l}\text { 2b. One of the HPV vaccines offers protection against genital } \\
\text { warts // Uma das vacinas contra HPV protege contra verrugas } \\
\text { genitais. }\end{array}$ & $0.930(0.891-0.960)$ & $0.984(0.991-0.975)$ & $0.484(0.198-0.770)$ \\
\hline $\begin{array}{l}\text { 2c. HPV vaccines offer protection against all sexually } \\
\text { transmitted infections // As vacinas contra o HPV protegem } \\
\text { contra todas as doenças sexualmente transmissíveis. }\end{array}$ & $0.939(0.905-0.965)$ & $0.984(0.991-0.975)$ & $0.538(0.144-0.932)$ \\
\hline $\begin{array}{l}\text { 2d. Someone who has an HPV vaccine cannot develop } \\
\text { cervical cancer // Quem foi vacinado contra o HPV não pode } \\
\text { desenvolver câncer de colo de útero. }\end{array}$ & $0.945(0.914-0.969)$ & $0.984(0.991-0.975)$ & $0.536(0.186-0.886)$ \\
\hline $\begin{array}{l}\text { 2e. HPV vaccines offer protection against most cervical cancers } \\
\text { // As vacinas contra o HPV protegem contra a maioria dos } \\
\text { cânceres de colo de útero. }\end{array}$ & $0.935(0.898-0.963)$ & $0.987(0.980-0.993)$ & $0.663(0.416-0.909)$ \\
\hline $\begin{array}{l}\text { 2f. The HPV vaccine requires three doses // A vacina contra o } \\
\text { HPV deve ser dada em } 3 \text { doses. }\end{array}$ & $0.926(0.884-0.958)$ & $0.984(0.975-0.991)$ & $0.809(0.602-1.000)$ \\
\hline $\begin{array}{l}2 \mathrm{~g} . \mathrm{HPV} \text { vaccines are most effective if given to people who } \\
\text { have never had sex // As vacinas contra o HPV são mais } \\
\text { eficazes se forem aplicadas em pessoas que nunca tiveram } \\
\text { relações sexuais. }\end{array}$ & $0.931(0.892-0.961)$ & $0.984(0.975-0.991)$ & $0.724(0.473-0.975)$ \\
\hline \multicolumn{4}{|l|}{ Subset 3} \\
\hline $\begin{array}{l}\text { 3a. If a woman tests positive for HPV she will definitely get } \\
\text { cervical cancer // Se o teste de HPV de uma mulher der } \\
\text { positivo, ela com certeza terá câncer de colo de útero. }\end{array}$ & $0.930(0.891-0.960)$ & $0.984(0.975-0.991)$ & $0.664(0.419-0.908)$ \\
\hline $\begin{array}{l}\text { 3b. A HPV test can be done at the same time as a Pap } \\
\text { smear test // A coleta de amostras para os testes de HPV e } \\
\text { Papanicolau pode ser feita ao mesmo tempo. }\end{array}$ & $0.939(0.905-0.965)$ & $0.984(0.975-0.991)$ & $0.599(0.337-0.861)$ \\
\hline $\begin{array}{l}\text { 3c. A HPV test can tell you how long you have had a HPV } \\
\text { infection // O teste de HPV pode indicar há quanto tempo você } \\
\text { teve uma infecção pelo HPV. }\end{array}$ & $0.930(0.891-0.960)$ & $0.984(0.975-0.991)$ & $0.417(0.116-0.719)$ \\
\hline $\begin{array}{l}3 \mathrm{~d} . \mathrm{HPV} \text { testing is used to indicate if the HPV vaccine is needed } \\
\text { // O teste de HPV serve para indicar se é preciso tomar a vacina } \\
\text { contra o HPV. }\end{array}$ & $0.635(0.430-0.793)$ & $0.986(0.978-0.992)$ & $0.667(0.425-0.909)$ \\
\hline $\begin{array}{l}\text { 3e. When you have a HPV test, you get the results the same } \\
\text { day // Quando você faz um teste de HPV, o resultado sai no } \\
\text { mesmo dia. }\end{array}$ & $0.635(0.430-0.793)$ & $0.986(0.978-0.992)$ & $0.448(0.127-0.770)$ \\
\hline $\begin{array}{l}\text { 3f. If a HPV test shows that a woman does not have HPV, her } \\
\text { risk of cervical cancer is low // Se o teste mostra que uma } \\
\text { mulher não tem HPV, o risco de ela ter câncer de colo de útero } \\
\text { é baixo. }\end{array}$ & $(0.431-0.793)$ & $0.986(0.978-0.992)$ & $0.000(0.000-0.000)$ \\
\hline
\end{tabular}

* Correlation tests and Cronbach's $\alpha$ were calculated using SPSS v. 20. To calculate 95\% confidence intervals (inside parentheses), Snedecor's F distribution 4 was used with the help of Microsoft Office Excel.

** Kappa agreement and respective confidence intervals were calculated with GraphPad. 


\section{Discussion}

The cross-culturally adapted Brazilian version of the measure of knowledge showed excellent results in terms of internal consistency. The proposed Brazilian version also showed high stability, since exclusion of single items generated only small variations in Cronbach's $\alpha$. Despite limitations in Cronbach's $\alpha$, the omission of certain items led to increased coefficients, suggesting its importance for the subscales and overall scale. The results of correlations between each item and the overall result showed a slight variation in the third subset. While there was a strong correlation in the first three items, the last three items showed moderate correlations. Hypothetically, this could be explained by the fact that these items were related to HPV testing, and participants might have difficulty understanding them. In the countries where the measurement tool was originally validated, the test is widely used, whereas in Brazil it is only performed in the private health system.

The test-retest results showed good reproducibility of the Brazilian version. However, low values found in two items may reflect some vulnerability of the measure or changes in the respondents' opinions between test and retest. It should be noted that knowledge level assessment is highly subjective, and certain items are related to individual behavior, which can require adequate knowledge of the subject.

\section{Contributors}

A. L. Manoel and F. Schuelter-Trevisol contribute to the study conception and design, data collection and analysis, and writing of the manuscript. J. Traebert contributed to the study design, data analysis, meeting with experts, and writing of the manuscript. L. C. Rebello contributed to the data collection and writing of the manuscript. C. M. Zapelini contributed to the data analysis and interpretation, meeting with experts, and writing of the manuscript. D. J. Trevisol contributed to the study conception and design, data analysis and interpretation, meeting with experts, and writing of the manuscript.
A possible limitation is that the study was developed in a southern Brazilian state. Although Portuguese is spoken all across the country, Brazil has continental dimensions and thus a variety of cultural contexts. This study used a self-administered online questionnaire based on the assumption that participants would feel more comfortable than in face-to-face interviews. In contrast, if the questionnaire is not self-explanatory and well formatted, it may raise doubts and lead to inadequate completion. No problems of this magnitude were detected in this study. However, although unplanned, some participants sent email messages to the researchers asking questions and offering suggestions on the scale. One statement that caused difficulty in understanding was "O teste de HPV e o Papanicolau podem ser feitos ao mesmo tempo" (The HPV test and Pap smear can be performed at the same time). The doubt was whether the statement referred to the diagnostic method itself or the sample collection. So, the statement was reworded to "A coleta da amostra para os testes de HPV e Papanicolau pode ser feita ao mesmo tempo" (Sample collection for the HPV test and Pap smear can be performed at the same time).

The preliminary model of the Brazilian Portuguese version of this instrument showed satisfactory reliability; however, further studies with larger samples are needed to test the measurement tool's reliability and validity.

\section{Acknowledgments}

The authors wish to thank Renata Bonetti Alves, Maria Luiza Kracik, Wilson Schuelter, and Stefano Demetrios for participating in the study as translators or backtranslators in the early stages of the cross-cultural adaptation process. 


\section{References}

1. Smith SJ, Lindsay L, Hoots B, Keys J, Franceschi S, Winer R, et al. Human papillomavirus type distribution in invasive cervical cancer and high-grade cervical lesions: a meta-analysis update. Int J Cancer 2007; 121:621-32.

2. Waller JO, Ostini R, Marlow LAV, McCaffery K, Zimet $\mathrm{G}$. Validation of a measure of knowledge about human papillomavirus (HPV) using item response theory and classical test theory. Prev Med 2013; 56:35-40.

\section{Resumo}

O objetivo deste artigo foi proceder às primeiras etapas de adaptação transcultural de um instrumento que mede o conhecimento sobre HPV para a língua portuguesa falada no Brasil. Foram realizadas a tradução inicial para o português brasileiro; sintese das versões traduzidas; retrotradução; análise por comitê de especialistas e análise de confiabilidade por intermédio da análise de consistência interna e de reprodutibilidade. $O$ coeficiente $\alpha$-Cronbach do instrumento foi estimado em 0,985. A análise por blocos implicou em pequenas variações. Os coeficientes de correlação entre cada questão e o resultado geral do instrumento mostraram correlações positivas fortes, com exceção de três questões. A análise de reprodutibilidade mostrou valores de kappa que evidenciaram concordâncias substanciais ou moderadas para a maioria das questões. Foi obtida uma primeira versão brasileira com resultados satisfatórios, mas outras etapas são necessárias ao processo de validação.

Papillomaviridae; Vacinas contra Papillomavirus; Questionários
3. Beaton DE, Bombardier C, Guillemin F, Ferraz MB Guidelines for the process of cross-cultural adaptation of self-report measures. Spine (Phila $\mathrm{Pa}$ 1976) 2000; 25:3186-91.

4. Maroco J. Qual a fiabilidade do alpha de Cronbach? Questões antigas e soluções modernas? Laboratório de Psicologia 2006; 4:65-90.

\section{Resumen}

El objetivo de este trabajo fue realizar las primeras etapas de la adaptación cultural un instrumento que mide los conocimientos sobre el VPH para el idioma portugués hablado en Brasil. Se realizó la traducción inicial para el portugués brasileño; síntesis de las versiones traducidas; retrotraducción; análisis por un Comité de Expertos y análisis de confiabilidad a través de la consistencia interna y reproducibilidad. El coeficiente $\alpha$-Cronbach del instrumento se estimó en 0,985. El análisis por bloques resultó en variaciones menores. Los coeficientes de correlación entre cada ítem y el resultado general del instrumento mostraron fuertes correlaciones positivas, a excepción de tres ítems. El análisis de la reproducibilidad mostró valores del kappa con concordancias sustanciales o moderadas para la mayoría de los ítems. Fue obtenida una primera versión brasileña con resultados satisfactorios, pero otros pasos son necesarios para el proceso de validación.

Papillomaviridae; Vacunas contra Papillomavirus; Cuestionarios
Submitted on $02 / J u n / 2015$

Final version resubmitted on 08/Apr/2016 Approved on 02/May/2016 